ACTA MYCOLOGICA

Vol. 49 (1): 3-21

2014
Dedicated to Professor Maria Ławrynowicz on the occasion of the 45th anniversary of her scientific activity

DOI: $10.5586 / \mathrm{am} .2014 .001$

\title{
Microfungi of the Tatra Mts. 6. Fungus-like organisms: Albuginales, Peronosporales and Pythiales
}

\author{
WIESŁAW MUŁENKO ${ }^{1}$, MONIKA KOZŁOWSKA ${ }^{1 *}$, \\ KAMILA BACIGÁLOVÁ2 ${ }^{2}$, URSZULA ŚWIDERSKA-BUREK ${ }^{1}$ \\ and AGATA WOLCZANSSKA ${ }^{1}$
}

\begin{abstract}
${ }^{1}$ Department of Botany and Mycology, Institute of Biology and Biochemistry, Maria Curie-Skłodowska University, Akademicka 19, PL-20-033 Lublin, *corresponding author: monika@ poczta.umcs.lublin.pl ${ }^{2}$ Institute of Botany, Slovak Academy of Sciences, Dúbravská cesta 9, SL-845 23 Bratislava 4
\end{abstract}

Mułenko W., Kozłowska M., Bacigálová K., Świderska-Burek U., Wołczańska A.: Microfungi of the Tatra Mts. 6. Fungus-like organisms: Albuginales, Peronosporales and Pythiales. Acta Mycol. 49 (1): 3-21, 2014.

A list and the distribution of Oomycota species in the Tatra Mts (Western Carpathian Mts) are presented. Revised herbarium vouchers and literature data were used for analysis. Thirty two species of oomycetes on fifty seven plant species were noted in the area, including two species of the order Albuginales (genera: Albugo and Pustula, on nine plant species), 29 species of the order Peronosporales (genera: Bremia, Hyaloperonospora, Peronospora and Plasmopara, on 49 plant species), and one species of the order Pythiales (genus: Myzocytium, on one species of algae). Twenty nine species were collected on the Polish side of the Tatra Mts and ten species were collected on the Slovak side. The oomycetes were collected at 185 localities.

Key words: microfungi, distribution, Oomycota, Western Carpathians, Poland, Slovakia

\section{INTRODUCTION}

The phylum Oomycota is a small group of approximately 1000 species (Kirk et al. 2008), including aquatic and terrestrial, parasitic and saprobic fungus-like organisms which cause numerous plant diseases. Peronosporales, which mainly consists of obligatory parasites of vascular plants, is the largest order in the phylum. Three families were previously distinguished in this order: the Albuginaceae, Peronosporaceae and Pythiaceae (Kochman, Majewski 1970). However, modern taxonomy classifies them as three separate orders: Albuginales, Peronosporales and Pythiales (Kirk et al. 2008).

Species of these orders that are economically important as causative agents of considerable losses in cultivated crops are well recognized and described. Many studies on these organisms are important taxonomic monographs comprising the 
entire order Peronosporales (in the former classification) (Kochman, Majewski 1974) or smaller taxonomic units [e.g. Plaats-Niterink (1981); Saharan et al. (1997)]. Much less is known about the diversity and abundance of these species in natural conditions, on plants growing in the wild. Only a few systematic studies of this group are identified in the Polish mycosociological literature spanning a period of over 50 years of research (Ławrynowicz et al. 2004). Downy mildews in alpine conditions were either not included in these studies or were investigated only sporadically.

The massif of the Tatra Mts is one of the most interesting alpine regions in central Europe and is almost entirely contained within national parks in Poland (TPN, Tatrzański Park Narodowy) and in Slovakia (TANAP, Tatranský Národný Park). It was declared a UNESCO Biosphere Reserve in 1992. While floristic, ecological, geological, hydrological and other research has been successfully conducted in the Tatra Mts (Vološčuk 1994; Mirek et al. 1996), detailed mycological investigations have not been carried out in the region. The geobotanical differentiation and the richness of plant species that are potential hosts of fungi in the region are high, and it can be expected that many interesting species of fungi and oomycetes, can occur in the area.

Results of studies to date indicate that microfungi in the Tatra Mts are poorly recognized. In-depth information on their ecology and distribution is not available and data are sometimes random. Consequently, information concerning the actual spread of fungi is highly differentiated and the data from individual areas of the Tatra Mts are considerably deficient. The majority of studies published so far are simple species lists or brief notes on a particularly interesting or rare species. Due to the lack of easy access to the area, analytical studies are undertaken infrequently (e.g. Urban 1952; Bacigálová et al. 2005; Mułenko et al. 2006, 2008). A similar problem is observed in other mountainous regions in Europe and worldwide.

The aim of our study was to summarize the existing literature data on the Oomycota occurring throughout the Tatra massif within the two national parks. More extensive research can be based on our results in the future. A similar study was carried out for representatives of the order Taphrinales in the mid-2000s (Bacigálová et al. 2005).

The present paper is part of the series named Parasitic Microfungi of the Tatra Mts. Five studies have been published to date: representatives of the order Taphrinales (Bacigálová et al. 2005), Pseudocercosporella tetrensis (Mułenko, Bacigálová 2005), Spermosporina gymnadeniae (Wołczańska et al. 2008), Melampsoridium hiratsukanum (Mułenko et al. 2005) and the Plasmopara spp. on the members of the genus Geranium (Mułenko et al. 2008). As only biotrophic species infect living plant organs and a considerable part of the collection are fungi occurring on decaying or dead organs (facultative parasites, facultative saprophytes), the word "parasitic" will now be omitted in the series title. Although this paper does not concern true fungi we left the name "microfungi" in the title of the series, because oomycetes are only a small part of all microorganisms which are published in this series. 


\section{HISTORY OF THE RESEARCH: AN OUTLINE}

Research into microfungi in the Tatra Mts goes back to the end of the $19^{\text {th }}$ century when Hazslinszky (1864) published a list of fungi collected in this area. The first information on downy mildews can be found in a study by Krupa (1886) and refers to Albugo candida on Arabis alpina on the Polish side of the Tatra Mts. In 1888 Krupa expanded the list of hosts by further four species: Arabis soyeri subsp. subcoriacea, Cardaminopsis halleri, Hutchinsia alpina and Kernera saxatilis. Data on oomycetes were published at the beginning of the $20^{\text {th }}$ century by Rouppert (1912), Wróblewski (1918, 1920, 1922a, 1922b, 1925) and Szulczewski (1930). The above-mentioned works included lists of species occurring on the Polish side of Tatra Mts. However, Wróblewski collected fungi on both sides of the border and was the first to publish information on microfungi in the Slovak part of the Tatra Mts. Further research in this region was carried out by Moesz (1930) and Picbauer (1933).

Mainly the Oomycota occurring on the Polish side of the Tatra Mts were discussed in the literature in the second half of the $20^{\text {th }}$ century: Starmachowa (1963), Kućmierz (1968), Kochman \& Majewski (1970), Sałata et al. (1984), RomaszewskaSałata et al. (1986), and Mułenko et al. (1995). A species parasitizing algae, Myzocytium megastomum on Closterium lunula, was reported in 1999 (Kadłubowska 1999). Only two studies investigating the Slovak side of the Tatra Mts were published in that period (Müller 1980, Skalický 1983).

Investigations in the Tatra National Park (TPN, TANAP) intensified in the late $20^{\text {th }}$ and early $21^{\text {st }}$ centuries. Results of studies conducted jointly with the Slovak Academy of Science (SAV) in the entire region of the Tatra Mts were first reported. For example, a detailed analysis of Plasmopara spp. on the members of Geranium was conducted by Mułenko et al. (2008). Specimens from the Tatra Mts were also examined during research into Plasmopara praetermissa, a species new to science (Voglmayr et al. 2006).

Both original results and summative studies have been reported in the literature. The first list of fungi of the Tatra Mts dates from the early $20^{\text {th }}$ century and can be found in a study on the fungi and slime moulds of two historical regions: Galicia and Bukovina (Namysłowski 1914). However, a monograph by Starmachowa (1963) is the first synthesis of microfungi. It comprises the entire Tatra Massif, i.e. both the Polish and the Slovak sides. The monograph was the main source of microfungirelated information for over thirty years until the late $20^{\text {th }}$ century.

An extensive discussion of the results of mycological research conducted in the Polish Tatra Mts was given in a monograph on the Tatra National Park (TPN, PL) (Sałata, Mułenko 1996). However, a list of species was not included due to both popular and scientific focus of the study. A full list of fungi and fungus-like organisms, considerably extended in comparison with the study by Starmachowa (1963), was published in 2004 (Mułenko et al.). A similar study for the Slovak part of the National Park was completed by Bacigálová (1999). 


\section{MATERIAL AND METHODS}

The list of species was based on literature reports published in the last 128 years. The oldest publications did not always contain detailed data. Some records were given in very general terms and only information that a species had been found in the Tatra Mts was reported while the location, site or study area were not indicated and the Polish or Slovakian part of the region was not specified.

Some of the specimens listed in this work have not survived. The majority, however, are deposited in the herbaria in Poland (KRA and KRAM in Kraków, WAUF in Warsaw, LBL in Lublin) and in Slovakia (SAV in Bratislava) (acronyms according to Holmgren et al. 1990). In some cases information from exsiccatum labels was used, which was not published previously. Wherever possible, we provided the habitat of the oomycetes listed.

\section{RESULTS}

Since 1886 a total of 32 species belonging to the Oomycota have been collected in the Tatra National Park. They are representatives of three orders: Albuginales (two species), Peronosporales (29 species) and Pythiales (one species). The fungus-like organisms were collected on 56 species of vascular plants and on one species of algae (Tab. 1).

The number of reported species is not very high and oomycetes are underexplored in the Tatra Mts. Mycosociological research in Poland to date shows that the abundance of the species of the Oomycota is greater, not only in considerably smaller regions but also in less floristically diversified areas. Majewski (1967) collected 58 species in the Puszcza Kampinoska forest, Kućmierz (1973) collected 59 species in

Table 1

General distribution of the oomycete in the Tatra Mts according to number of localities for each species

\begin{tabular}{|c|c|c|c|c|c|c|c|c|c|}
\hline \multirow[t]{2}{*}{ Species } & \multirow[t]{2}{*}{ Host plant } & \multicolumn{4}{|c|}{$\begin{array}{l}\text { Slovakia } \\
\text { number of } \\
\text { localities }\end{array}$} & \multicolumn{3}{|c|}{$\begin{array}{l}\text { Poland } \\
\text { number of } \\
\text { localities }\end{array}$} & \multirow[t]{2}{*}{$\begin{array}{c}\text { Total } \\
\text { number }\end{array}$} \\
\hline & & ZT & VT & BT & $W l$ & $\mathrm{TZ}$ & TW & $W l$ & \\
\hline \multicolumn{10}{|l|}{ Albuginales } \\
\hline \multirow[t]{8}{*}{ Albugo candida } & Arabis alpina & & 1 & 2 & & 7 & & & 10 \\
\hline & $\begin{array}{l}\text { Arabis soyeri subsp. } \\
\text { subcoriacea }\end{array}$ & & & & & 1 & & & 1 \\
\hline & Biscutella laevigata & & & 1 & & 3 & & & 4 \\
\hline & Capsella bursa-pastoris & & & & & 1 & & & 1 \\
\hline & Cardaminopsis arenosa & & & 1 & & 3 & & & 4 \\
\hline & Cardaminopsis halleri & & & & & 3 & & & 3 \\
\hline & Hutchinsia alpina & & & & & 2 & & & 2 \\
\hline & Kernera saxatilis & & & & & 1 & & & 1 \\
\hline Pustula tragopogonis & Cirsium palustre & & & & & & & 1 & 1 \\
\hline & & & 1 & 4 & & 21 & & 1 & 27 \\
\hline
\end{tabular}


Table 1 - cont.

\begin{tabular}{|c|c|c|c|c|c|c|c|c|}
\hline \multicolumn{9}{|l|}{ Peronosporales } \\
\hline \multirow[t]{10}{*}{ Bremia lactucae } & Carlina acaulis & & & & & 3 & & 3 \\
\hline & Cicerbita alpina & & & & & 1 & & 1 \\
\hline & Cirsium erisithales & & & & & 1 & & 1 \\
\hline & Crepis paludosa & & & & & 1 & & 1 \\
\hline & Hieracium aurantiacum & & & & & 1 & & 1 \\
\hline & Hieracium murorum & & & & & 1 & & 1 \\
\hline & Hieracium vulgatum & & 1 & & 1 & 6 & & 8 \\
\hline & Senecio subalpinus & & & & & 5 & & 5 \\
\hline & Senecio vulgaris & & & & & 1 & & 1 \\
\hline & Taraxacum officinale & & & & & 1 & & 1 \\
\hline $\begin{array}{l}\text { Hyaloperonospora arabidis- } \\
\text { alpinae }\end{array}$ & Arabis alpina & & & & & 1 & & 1 \\
\hline $\begin{array}{l}\text { Hyaloperonospora cardami- } \\
\text { nopsidis }\end{array}$ & Cardaminopsis arenosa & & & & & 1 & & 1 \\
\hline Hyaloperonospora lunariae & Lunaria rediviva & & & & & 3 & & 3 \\
\hline \multirow[t]{2}{*}{ Hyaloperonospora parasitica } & Cardamine amara & & & & & & 1 & 1 \\
\hline & Cardamine trifolia & & & & & 1 & & 1 \\
\hline Peronospora alpicola & Ranunculus platanifolius & & & & & & 3 & 3 \\
\hline Peronospora alta & Plantago major & & & & & 7 & & 7 \\
\hline Peronospora boni-henrici & $\begin{array}{l}\text { Chenopodium bonus- } \\
\text { henricus }\end{array}$ & & & & & 3 & & 3 \\
\hline \multirow[t]{3}{*}{ Peronospora conferta } & Cerastium fontanum & & & & & 2 & & 2 \\
\hline & Cerastium holosteoides & & & & & 2 & & 2 \\
\hline & Cerastium tatrae & & & & & 1 & & 1 \\
\hline Peronospora debaryi & Urtica urens & & & & & 1 & & 1 \\
\hline Peronospora erysimi & Erysimum hieraciifolium & & 1 & & & & & 1 \\
\hline \multirow[t]{2}{*}{ Peronospora galii } & Galium anisophyllon & & & & & 1 & & 1 \\
\hline & Galium schultesii & & & & & 3 & & 3 \\
\hline \multirow[t]{2}{*}{ Peronospora grisea } & Veronica beccabunga & & & & & 1 & & 1 \\
\hline & Veronica serpyllifolia & & & & & & 1 & 1 \\
\hline Peronospora knautiae & Scabiosa lucida & & & & & 3 & & 3 \\
\hline Peronospora mayorii & Vicia cracca & & 1 & & & & & 1 \\
\hline Peronospora myosotidis & Myosotis palustris & & & & & & 1 & 1 \\
\hline Peronospora phyteumatis & Phyteuma spicatum & & & & & 2 & & 2 \\
\hline Peronospora potentillae & Potentilla aurea & & 2 & & & 8 & & 10 \\
\hline \multirow[t]{2}{*}{ Peronospora ranunculi } & Ranunculus oreophilus & & & & & 1 & & 1 \\
\hline & Ranunculus repens & & & & & 3 & & 3 \\
\hline \multirow[t]{3}{*}{ Peronospora rumicis } & Rumex acetosa & & & & & 2 & & 2 \\
\hline & Rumex acetosella & & & & & 1 & & 1 \\
\hline & Rumex alpestris & & & & & 1 & & 1 \\
\hline Peronospora septentrionalis & Cerastium cerastoides & & & 1 & & & & 1 \\
\hline Peronospora sordida & Scrophularia scopolii & & & & & 3 & & 3 \\
\hline \multirow[t]{2}{*}{ Peronospora trifoliorum } & Lathyrus pratensis & & & & & 1 & & 1 \\
\hline & Trifolium repens & & & & & 1 & & 1 \\
\hline Peronospora violae & Viola biflora & & & & & 1 & & 1 \\
\hline Plasmopara densa & Rhinanthus serotinus & & & & & 1 & & 1 \\
\hline \multirow[t]{4}{*}{ Plasmopara geranii-silvatici } & Geranium palustre & 1 & & & & & & 1 \\
\hline & Geranium pratense & & & 1 & & 1 & & 2 \\
\hline & Geranium sylvaticum & 11 & 6 & 5 & & 19 & & 41 \\
\hline & Geranium sp. & & & 1 & & 1 & & 2 \\
\hline
\end{tabular}


Table 1 - cont.

\begin{tabular}{|c|c|c|c|c|c|c|c|c|c|}
\hline \multirow{3}{*}{ Plasmopara nivea } & Aegopodium podagraria & & & & & 2 & & & 2 \\
\hline & Anthriscus sylvestris & & & & & 1 & & & 1 \\
\hline & Mutellina purpurea & & 1 & & & & 1 & & 2 \\
\hline \multirow[t]{2}{*}{ Plasmopara praetermissa } & Geranium sylvaticum & 2 & 2 & 2 & & & 1 & & 7 \\
\hline & Geranium sp. & & & & & 1 & & & 1 \\
\hline \multirow[t]{2}{*}{ Plasmopara pusilla } & Geranium pratense & & 5 & & & 1 & & & 6 \\
\hline & Geranium sylvaticum & & 1 & & & 2 & & & 3 \\
\hline & & 14 & 20 & 10 & 1 & 104 & 8 & & 157 \\
\hline \multicolumn{10}{|l|}{ Pythiales } \\
\hline \multirow[t]{2}{*}{ Myzocytium megastomum } & Closterium lunula & & & & & 1 & & & 1 \\
\hline & & & & & & 1 & & & 1 \\
\hline Number of species & Number of host plants & \multicolumn{8}{|c|}{ Total number of localities } \\
\hline 32 & 57 & 14 & 21 & 14 & 1 & 126 & 8 & 1 & 185 \\
\hline
\end{tabular}

Denotations: ZT - Západné Tatry Mts (SK); VT - Vysoké Tatry Mts (SK); BT - Belianské Tatry Mts (SK); TZ - Tatry Zachodnie Mts (PL); TW - Tatry Wysokie Mts (PL); $W l$ - without precise localization

the Ojców National Park and 73 species in the Pieniny Mts (Kućmierz 1977). Similar investigations were carried out in the Bug river valley and in the Polesie National Park, from which 85 species (Danilkiewicz 1987) and 55 species (Mułenko 1988 a, b) were reported respectively. In other areas, however, a smaller number of oomycetes was noted. For instance, 36 species were recorded in the Białowieża National Park (Majewski 1971), 31 species in the Słowiński National Park (Adamska 2001), and 36 species in the Jura Krakowsko-Częstochowska upland (Ruszkiewicz-Michalska 2006).

As an analysis of the list of downy mildews in the Tatra Mts shows, the current state of knowledge of them varies considerably in Poland and Slovakia. The majority of species were reported from the Polish side of the Tatra Mts (29) while only ten were noted on the Slovak side (Tab. 2). The numbers of species found in individual parts of the Tatra Mts are highly divergent. The greatest numbers of fungus-like organisms were collected in the Western Tatras - 26 species. All of them (26 species) were recorded on the Polish side and only two on the Slovak side. Thirteen species were reported in the High Tatra Mts, including nine in Slovakia and six in Poland. Two of them (Plasmopara nivea and Plasmopara pratermissa) are common to both countries. Four species were recorded in the Belianské Tatry Mts, including one (Peronospora septentrionalis) that is known only from this region.

The spread of oomycetes, as measured by the number of existing localities, varies considerably. In total, fungus-like organisms were recorded at 185 localities. As

Table 2

Number of oomycete species in particular regions of Tatra Mts (denotations see Table 1)

\begin{tabular}{|c|c|c|c|c|c|c|}
\hline \multicolumn{2}{|c|}{ Slovakia } & \multicolumn{3}{c|}{ Poland } \\
\hline ZT & VT & BT & $W l$ & TZ & TW & $W l$ \\
\hline 2 & 9 & 4 & 1 & 26 & 6 & 1 \\
\hline \multicolumn{3}{|c|}{ Total number of species: 10 } & \multicolumn{2}{c|}{ Total number of species: 29 } \\
\hline
\end{tabular}


many as 135 records (73\%) were noted on the Polish side of the Tatra Mts and 126 $(68 \%)$ were found in the Western Tatra Mts. Oomycetes were noted at 50 localities on the Slovak side (27\%), mainly in the Vysoké Tatry Mts (21 records). The number of localities is the same in the remaining regions (Západné Tatry Mts and Belianské Tatry Mts; 14 in each) (Tab. 1).

Polyphagous species were recorded more frequently. They occurred sporadically on individual hosts. The most frequent combinations were: Albugo candida/Arabis alpina and Peronospora potentillae/Potentilla aurea (10 records each), Bremia lactucae/Hieracium vulgatum (8 records) and Peronospora alta/Plantago major ( 7 records). Of the above-mentioned species, only species of the genus Plasmopara occurring on Geranium spp. have been examined in greater depth in the last few years and the research data have been published (Mułenko et al. 2008). The species were found at 63 localities: 26 in the Polish and 37 in the Slovak part of the Tatra Mts. The study provides the only relatively objective results on the research into the spread of fungus-like organisms in the region available to date. There is a great need for further intensive and systematic research in the area.

\section{LIST OF OOMYCOTA}

Arrangement: The list of species is organized alphabetically by order name (Albuginales, Peronosporales, Pythiales) and by species name within the orders. Host plant species are listed alphabetically. Names of species of oomycetes are in bold. Names of doubtful species are not given in bold (see below).

Notes: Explanations are placed in two ways. If a note refers to a particular plant species (or an oomycete on this plant), it is placed at the end of the paragraph relating to the plant. If a note refers to a particular oomycete species (regardless of the host), it is placed as an independent paragraph below the list of host plants.

Doubtful species: Some species of oomycetes and of plants may be doubtful or may have been reported incorrectly. To retain the information given in the literature, names of such species are given in full but a note or a reference is added. Neither the name of an oomycete species nor the name of the plant is given in bold in such instances.

Names of oomycetes: Names of oomycetes are given after Kochman \& Majewski (1970), Constantinescu (1991), Thines \& Spring (2005), and Index Fungorum (http://www.indexfungorum.org/). Old names of oomycetes are given for some species, that is the names under which they were previously published, while some of them are not synonymous. Only the names cited in studies regarding this region are given in the synonyms.

Names of plants: Names of host plants are given after Mirek et al. (2002) and Marhold \& Hindak (1998). In some plant species their synonyms or their old names, under which they were published previously, are given. Only the names cited in studies referring to the Tatra Mts were used.

Division of the Tatra Mts: The entire Tatra Mts system is divided into regions differentiated on both sides of the Tatras: Western Tatra Mts - Tatry Zachodnie (PL) and Západné Tatry Mts (SK). Eastern Tatra Mts - Tatry Wysokie (PL), Vysoké Tatry Mts (SK) and Belianské Tatry Mts (SK). The respective regions of the Tatra Mts follow local names used on Tatra Mts tourist maps no. 112 and no. 113 (1:50.000), published by Vojensky kartograficky ustav (Harmanec, Slovakia, 1992-1996) and "Wielka Encyklopedia Tatrzańska" (Radwańska-Paryska \& Paryski 2004).

Abbreviations: TNP - Tatra National Park; PL - Polish side of the Tatra Mts; SK - Slovak side of the Tatra Mts; V-X - collection months.

Literature sources and citations: Not all the authors mentioned in the section "History of the research: an outline" provided data on their own collections. Many authors cited previously published information. This method is a common practice, particularly in the preparation of taxonomic or synthetic studies. However, the list of authors may be wrongly identified with a number of known locations in this way. Thus the original data source is given for each species in this study, whereas citations are provided separately and placed as supplementary information below the description of the locality. 
OOMYCOTA

\section{ALBUGINALES}

Albugo candida (Pers.) Roussel [Cystopus candidus (Pers.) Lév.]

- Arabis alpina L. TNP: PL - Tatry Zachodnie Mts: Dolina Strążyska valley; VIIVIII (Krupa 1886, 1888; Rouppert 1912; Starmachowa 1963). Dolina Kościeliska valley; VII-IX (Krupa 1888; Wróblewski 1918, 1922b). Dolina Mała Łąka valley; VIII-IX (Krupa 1888; Rouppert 1912). Dolina Białego valley; Mała Dolinka pod Giewontem valley; VII-VIII (Wróblewski 1922b). Przełęcz Iwaniacka pass; VII (Kućmierz 1968). Cited by Namysłowski (1914), Wróblewski (1920, 1925), Starmachowa (1963), Kochman \& Majewski (1970) and Mułenko et al. (2004). SK - Vysoké Tatry Mts: Belanská kopa Mt. at alt. 1690 m (Moesz 1930). Belianské Tatry Mts: Kopské sedlo pass; Tatranská Javorina village (Picbauer 1933). Cited by Starmachowa (1963) and Bacigálová (1999).

- Arabis soyeri Reut. \& A. Huet subsp. subcoriacea (Gren.) Breistr. (Arabis bellidifolia Jacq. non Crantz). TNP: PL - Tatry Zachodnie Mts: Hruby Regiel Mt. (Krupa 1888). Cited by Namysłowski (1914), Starmachowa (1963), Kochman \& Majewski (1970) and Mułenko et al. (2004).

- Biscutella laevigata L. TNP: PL - Tatry Zachodnie Mts: Dolina Strążyska valley; Mały Giewont Mt.; VI-VII (Wróblewski 1922b). Mały Giewont Mt. at alt. 1650 m, limestone bedrock; VIII (Sałata et al. 1984). Cited by Starmachowa (1963), Kochman \& Majewski (1970) and Mułenko et al. (2004). SK - Belianské Tatry Mts: Dolina Siedmich prameňov valley (Picbauer 1933). Cited by Starmachowa (1963) and Bacigálová (1999).

- Capsella bursa-pastoris (L.) Medik. TNP: PL - Tatry Zachodnie Mts: Dolina Kościeliska valley; VII, IX (Wróblewski 1918). Cited by Starmachowa (1963) and Mułenko et al. (2004).

- Cardaminopsis arenosa (L.) Hayek [Arabis arenosa (L.) Scop.]. TNP: PL - Tatry Zachodnie Mts: Dolina ku Dziurze valley (Szulczewski 1930). Dolina Białego valley at alt. $1000 \mathrm{~m}$, calcareous plants; Mały Giewont Mt. at alt. $1650 \mathrm{~m}$, limestone bedrock; VIII (Sałata et al. 1984). Cited by Starmachowa (1963) and Mułenko et al. (2004). SK - Belianské Tatry Mts: without localization at alt. 1320 m (?Bujačí vrch Mt.) (Moesz 1930). Cited by Starmachowa (1963) and Bacigálová [1999, incorrectly on Arabis hirsuta (L.) Scop.].

- Cardaminopsis halleri (L.) Hayek (Arabis halleri L.). TNP: PL - Tatry Zachodnie Mts: Kuźnice village (Krupa 1888). Dolina Strążyska valley; Dolina Kościeliska valley; VI, VIII (Wróblewski 1922b). Cited by Wróblewski (1920), Starmachowa (1963), Kochman \& Majewski (1970) and Mułenko et al. (2004).

- Hutchinsia alpina (L.) R. Br. (Lepidium alpinum L.). TNP: PL - Tatry Zachodnie Mts: Dolina za Bramką valley (Krupa 1888). Mała Dolinka pod Giewontem valley; VII (Wróblewski 1922b). Cited by Namysłowski (1914), Starmachowa (1963), Kochman \& Majewski (1970) and Mułenko et al. (2004).

- Kernera saxatilis (L.) Rchb. TNP: PL - Tatry Zachodnie Mts: Dolina Strążyska valley (Krupa 1888). Cited by Namysłowski (1914), Starmachowa (1963), Kochman \& Majewski (1970) and Mułenko et al. (2004).

Pustula tragopogonis (Pers.) Thines [Albugo tragopogonis (DC.) Gray, Cystopus tragopogonis Schröt.] 
- Cirsium palustre (L.) Scop. TNP: PL - Tatra Mts: without localization; VIII (Wróblewski 1922a, leg. J. Krupa, 1886). Cited by Starmachowa (1963) and

Kochman \& Majewski (1970).

Notes: The herbarium collections need revision because this oomycete was treated as a collective species occurring on representatives of the family Asteraceae according to Kochman \& Majewski (1970). This fungus-like organism can be divided into two species: Pustula tragopogonis and Pustula spinulosa.

\section{PERONOSPORALES}

Bremia lactucae Regel s.l.

- Carduus personata (L.) Jacq. Notes: reported by Kochman \& Majewski (1970) from Tatra Mts (without localization), however the collection was located in Zakopane town (WAUF, 01 Aug 1961, leg. J. Kochman).

- Carlina acaulis L. TNP: PL - Tatry Zachodnie Mts: Dolina Białego valley; Dolina Strążyska valley; Dolina za Bramką valley; VI (Wróblewski 1922b). Cited by Starmachowa (1963), Kochman \& Majewski (1970) and Mułenko et al. (2004).

- Carlina vulgaris L. Notes: Starmachowa (1963) and later Mułenko et al. (2004) wrongly reported presence of this oomycete at Toporowe Stawy lakes (PL) after Rouppert (1912). However, Rouppert (1912) did not mention this species. Similarly, Bacigálová (1999) reported the oomycete on this plant from Vysoké Tatry Mts (SK) after Picbauer (1933), however the latter author did not mention this information.

- Cicerbita alpina (L.) Wallr. TNP: PL - Tatry Zachodnie Mts: Ścieżka nad Reglami tourist route at alt. $1270 \mathrm{~m}$, herbaceous plants; VIII (Romaszewska-Sałata et al. 1986). Cited by Mułenko et al. (2004).

- Cirsium erisithales (Jacq.) Scop. TNP: PL - Tatry Zachodnie Mts: Dolina Spadowiec valley at alt. $910 \mathrm{~m}$, herbaceous plants; VIII (Sałata et al. 1984). Cited by Mułenko et al. (2004).

- Crepis paludosa (L.) Moench. TNP: PL - Tatry Zachodnie Mts: Dolina ku Dziurze valley at alt. $910 \mathrm{~m}$, spruce forest with Abies alba; VIII (Sałata et al. 1984). Cited by Mułenko et al. (2004).

- Hieracium aurantiacum L. TNP: PL - Tatry Zachodnie Mts: Niżnia Świstówka Mt. at alt. $1500 \mathrm{~m}$, grassland; IX (Mułenko et al. 1995). Cited by Mułenko et al. (2004).

- Hieracium murorum L. TNP: PL - Tatry Zachodnie Mts: Dolina Białego valley at alt. $960 \mathrm{~m}$, Dentario glandulosae-Fagetum; VIII (Sałata et al. 1984). Cited by Mułenko et al. (2004).

- Hieracium vulgatum Fr. TNP: PL - Tatry Zachodnie Mts: Dolina Olczyska valley at alt. $962 \mathrm{~m}$; Dolina ku Dziurze valley at alt. $970 \mathrm{~m}$; Dolina Strążyska valley at alt. $1020 \mathrm{~m}$; Boczań Mt. at alt. $1150 \mathrm{~m}$; Igła Mt. at alt. $1150 \mathrm{~m}$; Czoła Jaworzyńskie hill at alt. $1160 \mathrm{~m}$, spruce forest for all localities; VIII (Sałata et al. 1984). Cited by Mułenko et al. 2004. SK - Tatra Mts: without localization (Kochman \& Majewski 1970). Vysoké Tatry Mts: Štrbské pleso lake (Picbauer 1933). Cited by Starmachowa (1963) and Bacigálová (1999). Notes: The name of Hieracium vulgatum Fr. has not been changed because according to Mirek et 
al. (2002) it can be a synonym for 2 different species: Hieracium lachenalii C.C. Gmel and Hieracium laevicaule Jord.

- Senecio subalpinus W. D. J. Koch. TNP: PL - Tatry Zachodnie Mts: Dolina Kościeliska valley [WAUF, 26 July 1961, leg. T. Majewski; reported by Kochman \& Majewski (1970), without localization], Dolina Strążyska valley at alt. 900 m; Dolina ku Dziurze valley at alt. 920 m; Dolina Kościeliska valley (Stare Kościeliska) at alt. 940 m; Igła Mt. at alt. 1025 m, herbaceous plants for all localities; VIII (Sałata et al. 1984). Cited by Mułenko et al. (2004).

- Senecio vulgaris L. TNP: PL - Tatry Zachodnie Mts: Toporowe Stawy lakes; IX (Wróblewski 1918).

- Taraxacum officinale F. H. Wigg. TNP: PL - Tatry Zachodnie Mts: Dolina Kościeliska valley (KRAM, 10 Sept. 1966, leg. T. Majewski). Reported by Kochman \& Majewski (1970) on Taraxacum sp., without localization. Cited by Mułenko et al. (2004).

Hyaloperonospora arabidis-alpinae (Gäum.) Göker, Riethm.; Voglmayr, Weiss \& Oberw. [Peronospora arabidis-alpinae Gäum.]

- Arabis alpina L. TNP: PL - Tatry Zachodnie Mts: Ścieżka nad Reglami tourist route (near Zameczki rocks) at alt. $1200 \mathrm{~m}$, damp alpine grassland (Mułenko et al. 1995). Cited by Sałata \& Mułenko (1996) and Mułenko et al. (2004).

Hyaloperonospora cardaminopsidis (A. Gustavsson) Göker, Riethm. Voglmayr, Weiss \& Oberw. [Peronospora cardaminopsidis A. Gustavson]

- Cardaminopsis arenosa (L.) Hayek. TNP: PL - Tatry Zachodnie Mts: Mały Giewont Mt. at alt. 1650 m, limestone bedrock; VIII (Sałata et al. 1984). Cited by Mułenko et al. (2004.

Hyaloperonospora lunariae (Gäum.) Constant. [Peronospora lunariae Gäum.]

- Lunaria rediviva L. TNP: PL - Tatry Zachodnie Mts: Wąwóz Kraków ravine at alt. $1030 \mathrm{~m}$, herbaceous plants on limestone bedrock; VIII (Sałata et al. 1984) and 1000 m, scrub; VI-VIII (Mułenko et al. 1995). Dolina Kościeliska valley at alt. 980 m, Dentario glandulosae-Fagetum; VI-VIII (Mułenko et al. 1995). Cited by Sałata \& Mułenko (1996) and Mułenko et al. (2004).

Hyaloperonospora parasitica (Pers.) Constant. [Peronospora dentariae Rabenh., Peronospora parasitica (Pers.) Fr.]

- Cardamine amara L. TNP: PL - Tatry Wysokie Mts: Włosienica glade at alt. 1320 m, streamside; VI (Mułenko et al. 1995). Cited by Mułenko et al. (2004).

- Cardamine trifolia L. TNP: PL - Tatry Zachodnie Mts: Igła Mt. at alt. 1080 m, spruce forest; VIII (Sałata et al. 1984). Cited by Sałata \& Mułenko (1996) and Mułenko et al. (2004).

Notes: The oomycete was also reported by Wróblewski (1922b) on Hutchinsia alpina (L.) R. Br. (Lepidium alpinum L.) and later cited by Starmachowa (1963). See notes on Peronospora lepidii (belove).

Peronospora alpicola Gäum. [Peronospora ficariae auct. p.p.]

- Ranunculus platanifolius L. TNP: PL - Tatry Wysokie Mts: near Wodogrzmoty Mickiewicza waterfall; VII (Wróblewski 1922b). Morskie Oko lake at alt. 1405 $\mathrm{m}$, herbaceous plants; surroundings of Czarny Staw Gąsienicowy lake at alt. 1610 m, herbaceous plants in Pinetum mugo carpaticum; VIII (Sałata et al. 1984). Cited by Starmachowa (1963), Kochman \& Majewski (1970), Sałata \& Mułenko (1996) and Mułenko et al. (2004). 
? Peronospora alsinearum Casp. [Peronospora media Gäuman]. Notes: The oomycete was reported on Stellaria nemorum L. from Dolina Mała Łąka valley (TNP, PL) by Wróblewski (1922b), and later cited by Starmachowa (1963). However, Kochman \& Majewski (1970) did not find it in the herbarium specimen.

Peronospora alta Fuckel

- Plantago major L. TNP: PL - Tatry Zachodnie Mts: Dolina Chochołowska valley; VII (Kućmierz 1968). Dolina ku Dziurze valley at alt. 895 m; Dolina Białego valley at alt. 920 m; Dolina Kościeliska valley (Stare Kościeliska) at alt. 940 m; Dolina Olczyska valley at alt. 980 m; Kuźnice village at alt. 1051 m; Boczań Mt. at alt. $1150 \mathrm{~m}$, roadsides for all localities; VIII (Sałata et al. 1984). Cited by Sałata \& Mułenko (1996) and Mułenko et al. (2004).

Peronospora boni-henrici Gäum. [Peronospora effusa auct. p.p.]

- Chenopodium bonus-henricus L. TNP: PL - Tatry Zachodnie Mts: Kuźnice village; VI (Wróblewski 1922b). and at alt. 1053 m, roadside; VIII (Sałata et al. 1984). Dolina Chochołowska valley; VII (Kućmierz 1968).Cited by Starmachowa (1963), Kućmierz (1968), Kochman \& Majewski (1970) and Mułenko et al. (2004).

Peronospora conferta (Unger) Gäum. [Peronospora alsinearum auct. p.p.]

- Cerastium fontanum Baumg. TNP: PL - Tatry Zachodnie Mts: Kopa Królowa Mała Mt. at alt. $1455 \mathrm{~m}$, herbaceous plants in Pinetum mugo carpaticum; Giewont Mt. at alt. $1850 \mathrm{~m}$, calcareous grassland; VIII (Sałata et al. 1984). Cited by Mułenko et al. (2004).

- Cerastium holosteoides Fr. emend. Hyl. [Cerastium fontanum Baumg. subsp. triviale (Link) Jalas, Cerastium vulgatum L.]. TNP: PL - Tatry Zachodnie Mts: Dolina Jaworzynka valley at alt. 1080 m, grassland; Przełęcz między Kopami pass at alt. $1510 \mathrm{~m}$, roadside; VI (Mułenko et al. 1995).

- Cerastium tatrae Borbás (Cerastium raciborskii Zapał.). TNP: PL - Tatry Zachodnie Mts: Mała Dolinka pod Giewontem valley; VII (Wróblewski 1922b). Cited by Starmachowa (1963), Kochman \& Majewski (1970), Sałata \& Mułenko (1996) and Mułenko et al. (2004).

Peronospora debaryi E. S. Salmon \& Ware [Peronospora urticae (Lib.) de Bary]

- Urtica urens L. TNP: PL - Tatry Zachodnie Mts: Kuźnice village (Starmachowa 1963). Cited by Mułenko et al. (2004).

Peronospora erysimi Gaüm.

- Erysimum hieraciifolium L. TNP: SK - Vysoké Tatry Mts: between Popradské pleso lake and Popradské pleso railway station at alt. $1400 \mathrm{~m}$; VIII (Müller 1980). Cited by Bacigálová (1999, on Erysimum marschallianum Andrz. ex M. Bieb.). Notes: According to Marhold and Hindák (1998) Erysimum hieraciifolium L. is treated as a synonym of Erysimum marschallianum Andrz. ex Bieb., however in the Polish literature (Mirek et al. 2002) the two species are treated separately. We cite the original record in this case.

Peronospora galii Fuckel

- Galium anisophyllon Vill. TNP: PL - Tatry Zachodnie Mts: Mały Giewont Mt. at alt. $1650 \mathrm{~m}$, rock crevasse; VIII (Mułenko et al. 1995). Cited by Sałata \& Mułenko (1996) and Mułenko et al. (2004).

- Galium schultesii Vest. TNP: PL - Tatry Zachodnie Mts: Wąwóz Kraków ravine at alt. 1018 m, spruce forest with Abies alba; Grzybowiec Mt. at alt. 1175 m, spruce 
forest with Abies alba; VIII (Sałata et al. 1984). Dolina Białego valley at alt. 970 m, herbaceous plants; VI (Mułenko et al. 1995). Cited by Mułenko et al. (2004).

Peronospora grisea (Unger) de Bary

- Veronica beccabunga L. TNP: PL - Tatry Zachodnie Mts: Przełęcz Iwaniacka pass; VII (Kućmierz 1968). Cited by Mułenko et al. (2004).

- Veronica serpyllifolia L. TNP: PL - Tatry Wysokie Mts: Dolina Roztoki valley; VII (Wróblewski 1922b). Cited by Starmachowa (1963, as Peronospora verna Gäum.) and Mułenko et al. (2004).

? Peronospora hiemalis Gäum. Notes: The species was noted on Ranunculus lanuginosus L. from Dolina Kościeliska valley (PL) by Wróblewski (1922b), and later cited by Starmachowa (1963) and Mułenko et al. (2004). However, Kochman \& Majewski (1970) did not find it in the herbarium specimen.

Peronospora knautiae Fuckel

- Scabiosa lucida Vill. TNP: PL - Tatry Zachodnie Mts: Giewont Mt. - Suchy Żleb gully under Wrótka pass at alt. $1380 \mathrm{~m}$, calcareous grassland; VIII (Sałata et al. 1984). Hala Mała Łąka mountain pasture (Niżnia Świstówka - below Przełęcz Kondracka pass) at alt. $1500 \mathrm{~m}$ and $1600 \mathrm{~m}$, alpine grassland; IX (Mułenko et al. 1995). Cited by Sałata \& Mułenko (1996) and Mułenko et al. (2004).

? Peronospora lepidii (McAlp.) G. W. Wils. Notes: The species was reported by Wróblewski (1922b, as Peronospora parasitica) on Lepidium alpinum L. [Hutchinsia alpina (L.) R. Br.] from Mała Dolinka pod Giewontem valley (PL). However, Kochman \& Majewski (1970) did not find it in the herbarium specimen.

Peronospora mayorii Gäum.

- Vicia cracca L. TNP: SK - Vysoké Tatry Mts: Popradské pleso railway station at alt. 1280 m; VIII (Müller 1980). Cited by Bacigálová (1999).

Peronospora myosotidis de Bary

- Myosotis palustris (L.) L. emend. Rchb. (Myosotis scorpioides L.). TNP: PL Tatry Wysokie Mts: Hala Gąsienicowa mountain pasture at alt. $1530 \mathrm{~m}$, herbaceous plants; VI (Mułenko et al. 1995). Cited by Mułenko et al. (2004).

Peronospora phyteumatis Fuckel

- Phyteuma spicatum L. TNP: PL - Tatry Zachodnie Mts: Dolina Białego valley at alt. $910 \mathrm{~m}$, spruce forest with Abies alba; Dolina Spadowiec valley at alt. $915 \mathrm{~m}$, spruce forest with Abies alba; VIII (Sałata et al. 1984). Cited by Mułenko et al. (2004).

Peronospora potentillae de Bary

- Potentilla aurea L. TNP: PL - Tatry Zachodnie Mts: Dolina Chochołowska valley; VII (Kućmierz 1968). Dolina Olczyska valley at alt. 950 m; Stara Polana glade at alt. 1060 m; Dolina Bystrej valley at alt. 1124 m; Czoła Jaworzyńskie hill at alt. 1195 m; Czerwona Przełęcz pass at alt. 1303 m; Giewont Mt. (Piekło) at alt. 1405 m; Kopa Magury Mt. at alt. 1560 m, grasslands for all localities; VIII (Sałata et al. 1984). Cited by Sałata \& Mułenko (1996) and Mułenko et al. (2004). SK - Vysoké Tatry Mts: Mlynická dolina valley (near Štrbské pleso lake) at alt. 1350 m, spruce forest; VIII (Müller 1980). Bielovodská dolina valley; VII (Skalický 1983). Cited by Bacigálová (1999).

Peronospora ranunculi Gäum. [Peronospora ficariae auct. p.p.]

- Ranunculus flammula L. Notes: reported by Kochman \& Majewski (1970) from Tatra Mts after Wróblewski (1922b), however in the last paper it was located in Zakopane town. 
- Ranunculus lanuginosus $\rightarrow$ see notes on Peronospora hiemalis.

- Ranunculus oreophilus M. Bieb. TNP: PL - Tatry Zachodnie Mts: Nosal Mt. at alt. $1150 \mathrm{~m}$, alpine grassland; VI (Mułenko et al. 1995). Cited by Mułenko et al. (2004).

- Ranunculus platanifolius $\rightarrow$ see Peronospora alpicola.

- Ranunculus repens L. TNP: PL - Tatry Zachodnie Mts: Dolina Kościeliska valley; VIII (Wróblewski 1922b). Kuźnice village; Giewont Mt. - Suchy Żleb gully under Wrótka pass (Starmachowa 1963). Cited by Starmachowa (1963) and Mułenko et al. (2004).

Peronospora rumicis Corda

- Rumex acetosa L. TNP: PL - Tatry Zachodnie Mts: Dolina Mała Łąka valley; VI (Wróblewski 1922b). Dolina Chochołowska valley; VII (Kućmierz 1968). Cited by Starmachowa (1963) and Mułenko et al. (2004).

- Rumex acetosella L. TNP: PL - Tatry Zachodnie Mts: Polana Chochołowska glade; VII (Kućmierz 1968). Cited by Mułenko et al. (2004, incorrectly reported after Starmachowa 1963 instead of Kućmierz l.c.).

- Rumex alpestris Jacq. (Rumex arifolius All.). TNP: PL - Tatry Zachodnie Mts: Mała Dolinka pod Giewontem valley; VIII (Wróblewski 1922b). Cited by Starmachowa (1963), Kochman \& Majewski (1970), Sałata \& Mułenko (1996) and Mułenko et al. (2004).

Peronospora septentrionalis Gäum.

- Cerastium cerastoides (L.) Britton (Cerastium trigynum Vill.). TNP: SK - Belianské Tatry Mts: Kopské sedlo pass (Picbauer 1933). Cited by Starmachowa (1963) and Bacigálová [1999, on Dichodon cerastoides (L.) Rchb.].

Peronospora sordida Berk.

- Scrophularia scopolii Hoppe. TNP: PL - Tatry Zachodnie Mts: Dolina Strążyska valley; Mała Dolinka pod Giewontem valley; Dolina Kościeliska valley; VI-VII (Wróblewski 1922b). Cited by Starmachowa (1963), Kochman \& Majewski (1970) and Mułenko et al. (2004).

Peronospora trifoliorum de Bary [Peronospora fulva Syd.]

- Lathyrus pratensis L. TNP: PL - Tatry Zachodnie Mts: Dolina Kościeliska valley (Stare Kościeliska) at alt. 960 m, meadow; VI (Mułenko et al. 1995). Cited by Mułenko et al. (2004).

- Trifolium repens L. TNP: PL - Tatry Zachodnie Mts: Kuźnice village at alt. 1051 $\mathrm{m}$, roadside; VIII (Sałata et al. 1984). Cited by Mułenko et al. (2004).

Peronospora violae de Bary

- Viola biflora L. TNP: PL - Tatry Zachodnie Mts: Dolina Strążyska valley; VI (Wróblewski 1922b). Cited by Starmachowa (1963), Kochman \& Majewski (1970) and Mułenko et al. (2004).

Plasmopara densa (Rabenh.) J. Schröt.

- Rhinanthus serotinus (Schönh.) Oborný [Alectorolophus glaber (Lam.) Beck]. TNP: PL - Tatry Zachodnie Mts: Polana Kalatówki mountain pasture (Starmachowa 1963). Cited by Mułenko et al. (2004).

Plasmopara geranii-silvatici Săvul. \& O. Săvul.

- Geranium palustre L. TNP: SK - Západné Tatry Mts: Jalovská dolina valley at alt. $740 \mathrm{~m}$, roadside in spruce forest; VII (Mułenko et al. 2008). 
- Geranium pratense L. TNP: PL - Tatry Zachodnie Mts: Polana Olczyska glade at alt. 1050 m, meadow; VI (Mułenko et al. 1995, as Plasmopara pusilla). Cited by Mułenko et al. (2008). SK - Belianské Tatry Mts: Dolina Siedmich prameňov valley at alt. $900 \mathrm{~m}$, roadside in spruce forest; VII (Mułenko et al. 2008).

- Geranium sylvaticum L. TNP: PL - Tatry Zachodnie Mts: Polana Kalatówki mountain pasture at alt. 1225 m, herbaceous plants; VIII (Sałata et al. 1984, as Plasmopara pusilla). Dolina Olczyska valley (Polana Olczyska glade) at alt. $1059 \mathrm{~m}$ and $1115 \mathrm{~m}$, meadow; Dolina Jaworzynka valley at alt. $1100 \mathrm{~m}$, meadow; Dolina Miętusia valley at alt. 1120 m and 1180 m; Ścieżka nad Reglami tourist route (between Dolina Mała Ląka valley and Przysłop Miętusi pass) at alt. 1158 m, meadow; Przysłop Miętusi pass at alt. 1165 m, meadow; Dolina Kościeliska valley (between Ornak shelter house and Iwaniacka Przełęcz pass) at alt. $1220 \mathrm{~m}$, herbaceous plants; tourist route between Przysłop Miętusi pass and Małołączniak Mt. at alt. 1342 m, $1362 \mathrm{~m}$ and $1394 \mathrm{~m}$, spruce forest; Giewont Mt. - Suchy Żleb gully under Wrótka pass at alt. $1350 \mathrm{~m}$, herbaceous plants on screen slope; Dolina Tomanowa valley at alt. $1351 \mathrm{~m}$, spruce forest; Hala Miętusia mountain pasture at alt. 1410 m and 1470 m; Dolina Mała Łąka valley (between Hala Mała Łąka mountain pasture and Przełęcz Kondracka pass) at alt. $1450 \mathrm{~m}$, herbaceous plants; Iwaniacka Przełęcz pass at alt. 1460 m, herbaceous plants; VI-VIII (Mułenko et al. 2008). Cited by Mułenko et al. (2008). SK - Západné Tatry Mts: Javorová dolina valley (near Tichá dolina valley) at alt. $1110 \mathrm{~m}$, meadow; VIII (Voglmayr et al. 2006; Mułenko et al. 2008). Javorový žl'ab gully (from the side of Tomanovská dolina valley) at alt. 1120 m; Roháčska dolina valley (blue tourist route to Spálena dolina valley) at alt. $1200 \mathrm{~m}$; Kamenistá dolina valley at alt. $1200 \mathrm{~m}$ and $1340 \mathrm{~m}$; Tichá dolina valley at alt. $1260 \mathrm{~m}$; Tomanovská dolina valley at alt. $1260 \mathrm{~m}$; Žiarska dolina valley (near Žiarska chata shelter house) at alt. $1289 \mathrm{~m}$ and $1320 \mathrm{~m}$, herbaceous plants; between Žiarska chata shelter house and Malé Závraty cirque at alt. $1540 \mathrm{~m}$, Pinetum mughi carpaticum; red tourist route between Pálenica and Sivý vrch Mt. at alt. 1640 m; VIII (Mułenko et al. 2008). Vysoké Tatry Mts: Tatranská Lomnica town at alt. 860 m; Dolina Kežmarskej Bielej vody valley at alt. $920 \mathrm{~m}$, roadside in spruce forest and $1090 \mathrm{~m}$, spruce forest; Dolina Bielych Plies valley at alt. 1526 m, $1600 \mathrm{~m}$ and $1671 \mathrm{~m}$, Pinetum mughi carpaticum; VII-IX (Mułenko et al. 2008). Belianské Tatry Mts: Dolina Siedmich prameňov valley (below chata Plesnivec shelter house) at alt. $1140 \mathrm{~m}$ and 1150 m, herbaceous plants; near chata Plesnivec shelter house at alt. $1270 \mathrm{~m}$; Zadné Med'odoly valley at alt. $1400 \mathrm{~m}$ and $1410 \mathrm{~m}$, herbaceous plants; VII-IX (Mułenko et al. 2008).

- Geranium sp. TNP: PL - Tatry Zachodnie Mts: Ścieżka nad Reglami tourist route (between Dolina Mała Łąka valley and Dolina Strążyska valley) at alt. 1240 m; IX (Mułenko et al. 2008). SK - Belianské Tatry Mts: Monkova dolina valley at alt. $1650 \mathrm{~m}$, mountain pasture, herbaceous plants; VIII (Mułenko et al. 2008).

Plasmopara nivea (Unger) J. Schröt. [Plasmopara aegopodii (Casp.) Trotter, Plasmopara umbelliferarum (Casp.) Schröt. ex Wartenw.]

- Aegopodium podagraria L. TNP: PL - Tatry Zachodnie Mts: Dolina Olczyska valley (Starmachowa 1963). Dolina Chochołowska valley at alt. 1100 m, meadow; VII (Mułenko et al. 1995). Cited by Mułenko et al. (2004). 
- Anthriscus sylvestris (L.) Hoffm. TNP: PL - Tatry Zachodnie Mts: Polana Olczyska glade at alt. 1050 m, meadow; VI (Mułenko et al. 1995). Cited by Mułenko et al. (2004).

- Mutellina purpurea (Poir.) Thell. [Ligusticum mutellina (L.) Crantz., Meum mutellina (L.) Gaertn.]. TNP: PL - Tatry Wysokie Mts: Morskie Oko lake; VIII (Stec-Rouppertowa 1936). Cited by Starmachowa (1963), Kochman \& Majewski (1970) and Mułenko et al. (2004). SK - Vysoké Tatry Mts: Temnosmrečinská dolina valley; VIII (Wróblewski 1922b). Cited by Starmachowa (1963) and Bacigálová (1999, incorrectly from Západné Tatry Mts).

Note: Information on the species was also cited in a paper by Sałata and Mułenko (1996).

Plasmopara praetermissa Voglmayr, Faethi \& Constant.

- Geranium sylvaticum L. TNP: PL - Tatry Wysokie Mts: tourist route between Morskie Oko lake and Szpiglasowy Wierch Mt. at alt. 1600 m, Pinetum mughi carpaticum; IX (Mułenko et al. 2008). SK - Západné Tatry Mts: Zadná Tichá dolina valley at alt. $1520 \mathrm{~m}$, Pinetum mughi carpaticum; VII (Voglmayr et al. 2006; Mułenko et al. 2008). Tichá dolina valley (tourist route to Kasprov vrch Mt.) at alt. 1265 m, meadow; VIII (Mułenko et al. 2008). Vysoké Tatry Mts: Dolina Bielych plies valley at alt. 1600 m, Pinetum mughi carpaticum; Zlomisková dolina valley at alt. $1640 \mathrm{~m}$, herbaceous plants in Pinetum mughi carpaticum; VIII (Mułenko et al. 2008). Belianské Tatry Mts: Dolina Siedmich prameňov valley at alt. $1100 \mathrm{~m}$; Zadné Med'odoly valley at alt. $1350 \mathrm{~m}$, meadow; VII-VIII (Mułenko et al. 2008).

- Geranium sp. TNP: PL - Tatry Zachodnie Mts: Wielka Polana Małołącka glade at alt. $1161 \mathrm{~m}$, meadow; VI (Mułenko et al. 2008).

Plasmopara pusilla (de Bary) J. Schröt.

- Geranium pratense L. TNP: SK - Vysoké Tatry Mts: Tatranská Lomnica town - Centre at alt. $860 \mathrm{~m}$ and park near hotel Morava at alt. $880 \mathrm{~m}$ and $900 \mathrm{~m}$, roadside; Stará Lesná village - road between Academia hotel and Tatranská Lomnica town at alt. $800 \mathrm{~m}$, roadside; Dolina Kežmarskej Bielej vody valley at alt. $1100 \mathrm{~m}$; VII-VIII (Mułenko et al. 2008).

- Geranium sylvaticum L. TNP: PL - Tatry Zachodnie Mts: Giewont Mt. - Suchy Żleb gully under Wrótka pass at alt. $1385 \mathrm{~m}$, herbaceous plants; VIII (Sałata et al. 1984). Cited by Mułenko et al. (2004). SK - Vysoké Tatry Mts: between Popradské pleso lake and Popradské pleso railway station at alt. $1380 \mathrm{~m}$, spruce forest; VIII (Müller 1980). Cited by Bacigálová (1999).

Notes: The herbarium specimen collected by Müller was not reidentified. The plant may have been infected by Plasmopara geranii-sylvatici. The data by Sałata et al. (1984: Suchy Żleb gully, see above) are doubtful. The specimen was not preserved. It is likely to be Plasmopara geranii-sylvatici Sãvul. \& O. Sãvul. (Mułenko et al. 2008).

This species was also noted on Geranium pratense L. (Mułenko et al. 1995) and on Geranium sylvaticum L. (Sałata et al. 1984), and later cited by Mułenko et al. (2004). The specimens were reidentified and included in Plasmopara geranii-sylvatici. 
PYTHIALES

\section{Myzocytium megastomum De Wild.}

- Closterium lunula (Müller) Nitzsch. (Algae). TNP: PL - Tatry Zachodnie Mts: Dolina Gąsienicowa valley - Toporowe Stawy lakes; IX (Kadłubowska 1999).

Acknowledgements. The study is part of two grants of the Polish Ministry of Science and Higher Education (PL): No 2/04C/089/27 and No N/N304/172436, and also by VEGA grant agency (SK): No. 2/4032/04.

\section{REFERENCES}

Adamska I. 2001. Microscopic fungus-like organisms and fungi of the Słowiński National Park (NW Poland). II. Acta Mycol. 36 (1): 31-65.

Bacigálová K. 1999. Microscopic phytopathogenic fungi in High Tatra Mts. I. Štúdie o Tatranskom Národnom Parku 4 (37): 4170 (in Slovak with English summary).

Bacigálová K., Mułenko W., Wołczańska A. 2005. Parasitic microfungi of the Tatra Mts. 1. Taphrinales. Pol. Bot. J. 50 (2): 185-207.

Choi Y.J., Thines M., Piątek M., Shin H.D. 2012. Morphological evidence supports the existence of multiple species in Pustula (Albuginaceae, Oomycota). Nova Hedwigia 94: 181-192. http://dx.doi. org/10.1127/0029-5035/2012/0094-0181

Constantinescu M. 1991. An annotated list of Peronospora names. Thunbergia 15:1-110.

Danilkiewicz M. 1987. Parasitic fungi of river Bug valley. Acta Mycol. 23 (2): 37-80 (in Polish with English abstract and summary).

Hazslinszky F. 1864. Beiträge zur Kenntnis der Karpathenflora IX. Brandpilze. Verh. Zool.-Bot. Ges. Wien 14: 169-190.

Holmgren P. K., Holmgren N. H., Barnett L. C. 1990. Index Herbariorum. Part I: The herbaria of the world. Ed. 8. Regnum Veg. 120: 1-693.

Index Fungorum, retrieved 2013-04-17 from http://www.indexfungorum.org/.

Kadłubowska J. 1999. Rare species of fungi parasiting on algae. II. Parasites of Desmidiaceae. Acta Mycol. 34 (1): 51-54.

Kirk P.M., Cannon P.F., Minter D.W., Stalpers J.A. 2008. Ainsworth, Bisby's Dictionary of the Fungi. $10^{\text {th }}$ Edition. CABI International.

Kochman J., Majewski T. 1970. Glonowce (Phycomycetes), wroślikowe (Peronosporales). (In:) J. Kochman, A. Skirgiełło (eds). Flora polska, Grzyby (Mycota) 4. Państwowe Wydawnictwo Naukowe, Warszawa.

Krupa J. 1886. Zapiski mykologiczne przeważnie z okolic Lwowa i z Tatr. Kosmos 11: 370-399.

Krupa J. 1888. Zapiski mykologiczne z okolic Lwowa i z Podtatrza. Spraw. Kom. Fizjogr. 22: 12-47.

Kućmierz J. 1968. A contribution to the knowledge of parasitic fungi of the Tatra Mts. Fragm. Florist. Geobot. 14 (2): 243-250 (in Polish with English summary).

Kućmierz J. 1973. The parasitic fungi in the Ojców National Park. Ochrona Przyrody 38: 155-211 (in Polish with English summary).

Kućmierz J. 1977. Investigation on the parasitic fungi from the Pieniny Mts. Zesz. Nauk. AR w Krakowie, Rozprawy 52: 1-142 (in Polish with English and Russian summary).

Ławrynowicz M., Bujakiewicz A., Mułenko W. 2004. Mycocoenological studies in Poland. 1952-2002. Monogr. Bot. 93: 1-102.

Majewski T. 1967. Contribution to the mycoflora of parasiting fungi in the Kampinos Forests. Acta Mycol. 3: 115-151 (in Polish with English summary).

Majewski T. 1971. Parasitic fungi of the Białowieża National Park against the background of the mycoflora of Poland (Peronosporales, Erysiphales, Uredinales, Ustilaginales). Acta Mycol. 7: 299-388 (in Polish with English summary).

Marhold K., Hindák F. (eds). 1998. Zoznam nižších a vyšších rastlín Slovenska, pp. 687. Veda, Bratislava, $687 \mathrm{pp}$. 
Mirek Z., Głowaciński Z., Klimek K., Piękoś-Mirkowa H. (eds) 1996. Nature of the Tatra National Park. Tatry i Podtatrze 3: 787 pp. Wyd. Tatrzański Park Narodowy, Kraków-Zakopane (in Polish with English summaries).

Mirek Z., Piękoś-Mirkowa H., Zając A., Zając M. 2002. Flowering plants and pteridophytes of Poland. A checklist. W. Szafer Institute of Botany, Polish Academy of Sciences, Kraków.

Moesz G. 1930. Pilze aus dem Norden Ungarns. Folia Cryptog. 1 (7): 795-816.

Müller J. 1980. Contribution towards the knowlwdge of rusts, smuts and downy mildew in High Tatras. Biologia (Bratislava) 35 (7): $497-504$ (in Czech with Russian summary and English abstract).

Mułenko W. 1988a. The microscopic pathogenic fungi of the Lęczna-Włodawa Lake District. I. The occurrence of pathogenic fungi in plant communities and theirs phenology. Acta Mycol. 24 (1): 3-49 (in Polish with English summary).

Mułenko W. 1988b. The microscopic pathogenic fungi of the Łęczna-Włodawa Lake District. II. Acta Mycol. 24 (2): 125-171 (in Polish with English summary).

Mułenko W., Bacigálová K. 2005. Parasitic microfungi of the Tatra Mts. 2. Pseudocercosporella tatrensis sp. nov. on Aconitum firmum subsp. firmum from Poland. Pol. Bot. J. 50 (2): 209-212.

Mułenko W., Bacigálová K., Kozłowska M. 2005. Parasitic microfungi of the Tatra Mts. 4. Melampsoridium hiratsukanum (Urediniomycetes). Pol. Bot. Stud. 22: 399-405.

Mułenko W., Bacigálová K., Wołczańska A., Świderska U., Mamczarz M. 2008. Parasitic microfungi of the Tatra Mts. 5. Plasmopara representatives on the species of Geranium. Biologia (Bratislava) 63(3): 302-306.

Mułenko W., Kozłowska M., Sałata B. 2004. Microfungi of the Tatra National Park. A checklist. Biodiversity of the Tatra National Park. Vol. 1: pp. 68. W. Szafer Institute of Botany, Polish Academy of Sciences, Kraków.

Mułenko W., Sałata B., Wołczańska A. 1995. Mycological notes from the Tatra National Park. II. Acta Mycol. 30 (1): 65-79.

Mułenko W., Wołczańska A., Bacigálová K. 2006. Taphrinales (Ascomycota) in the Tatra Mountains. Analysis of occurrence. (In:) Z. Mirek, B. Godzik (eds). Przyroda Tatrzańskiego Parku Narodowego a Człowiek. 2005. Tatrzański Park Narodowy na tle innych górskich terenów chronionych. Vol. II. Nauki Biologiczne. Kraków-Zakopane 2006: 29-33. Wyd. Tatrzańskiego Parku Narodowego (in Polish with English summary).

Namysłowski B. 1914. Śluzowce i grzyby Galicyi i Bukowiny. Pam. Fizjogr. 22: 1-151.

Radwańska-Paryska Z., Paryski W. H. 2004. Wielka Encyklopedia Tatrzańska. Wydawnictwo Górskie, Poronin, $1555 \mathrm{pp}$.

Picbauer R. 1933. Addenda ad floram Čechoslovakiae mycologicam. VII. Práce Morav. Př́r. Společn. 8 (8): 1-20.

Plaats-Nitterink, A.J.Van Der.1981. Monograph of the Genus Pythium. Stud. Mycol., 21: 1-244. Centraalbureau voor Schimmelcultures, Utrecht, Nederlands.

Romaszewska-Sałata J., Sałata B., Mułenko W. 1986. On some interesting representatives of Peronosporales and Erysiphales collected recently in Poland. Folia Soc. Sci. Lubl., Biologia 28 (1): 11-18 (in Polish with English and Russian summaries).

Rouppert K. 1912. Pilze aus der Tatra und den Westlichen Beskiden. Spraw. Kom. Fizjogr. 46: 80-100 (in Polish with German summary).

Ruszkiewicz-Michalska M. 2006. Phytoparasitic micromycetes in plant communities of the Wyżyna Częstochowska Upland. Monogr. Bot. 96: 1-140 (in Polish with English summary).

Sałata B., Mułenko W. 1996. Microscopic phytopathogenic fungi. (In:) Z. Mirek, Z. Głowaciński, K. Klimek, H. Piękoś-Mirkowa (eds). Nature of the Tatra National Park. Tatry i Podtatrze 3: 393-404. Tatrzański Park Narodowy, Zakopane-Kraków (in Polish with English summary).

Sałata B., Romaszewska-Sałata J., Mułenko W. 1984. Mycological notes from the Polish Tatra National Park. Acta Mycol. 20(1): 13-21 (in Polish with English abstract).

Saharan G. S., Verna P. R. Noshaat N. J. 1997. Monograph on downy mildew of crucifers. Technical Bulletin - Agriculture and Agri-Food, Canada, 208 pp.

Skalický V. 1983. The revision of species of the genus Peronospora on host plant of the family Rosaceae with respect to Central European species. Folia Geobot. Phytotax. 18: 71-101.

Starmachowa B. 1963. Les champignons parasitaires des Tatras. Monogr. Bot. 15: 153-294 (in Polish with French summary).

Stec-Rouppertowa W. 1936. Zapiski mikologiczne. Spraw. Kom. Fizjogr. 70: 149-172. 
Szulczewski J. W. 1930. Die Gallen des polnischen Tatragebriges. Spraw. Kom. Fizjogr. 64: 1-11 (in Polish with German summary).

Thines M., Spring O. 2005. A revision of Albugo (Chromista, Peronosporomycetes). Mycotaxon 92: 443458.

Urban Z. 1952. Hrdze a sneti v Temnosmrečinovej doline vo Vysokých Tatrách. Slovenská Akadémie Vied a Umeni, Bratislava (in Czech with Russian summary).

Voglmayr H., Fatehi J., Constantinescu O. 2006. Revision of Plasmopara (Chromista, Peronosporales) parasitic on Geraniaceae. Mycol. Res. 110: 633-645. http://dx.doi.org/10.1016/j.mycres.2006.03.005

Vološčuk I. (ed.). 1994. Tatranský Národný Park. Biosférická rezervácia. Vyd. GRADUS, Martin.

Wołczańska A., Mułenko W., Oklejewicz K., Bacigálová K. 2008. Parasitic microfungi of the Tatra Mts. 3. Spermosporina gymnadeniae - new species for Slovakia and new records in Poland. Biologia 63(1): 50-52.

Wróblewski A. 1918. Beitrag zur Kenntnis der Pilzflora Westgaliziens. Spraw. Kom. Fizjogr. 52: 122-127 (in Polish with German summary).

Wróblewski A. 1920. Grzyby zbioru Józefa Krupy. Spraw. Kom. Fizjogr. 53-54: 83-94.

Wróblewski A. 1922a. Les champignons recueillés par J. Krupa. Kosmos 47 (1-3): $39-51$ (in Polish with French summary).

Wróblewski A. 1922b. Wykaz grzybów zebranych w latach 1913-1918 z Tatr, Pienin, Beskidów Wschodnich, Podkarpacia, Podola, Roztocza i innych miejscowości. I. Phycomycetes, Ustilaginaceae, Uredinales i Basidiomycetes. Spraw. Kom. Fizjogr. 55-56: 1-50.

Wróblewski A. 1925. Champignons recueillis par M. Raciborski dans les environs de Cracovie et dans le Tatra en 1883 et 1890. Acta Soc. Bot. Pol. 3 (1): 29-41 (in Polish with French summary).

Grzyby mikroskopijne Tatr. 6. Organizmy grzybopodobne: Albuginales, Peronosporales i Pythiales

\section{Streszczenie}

Masyw Tatr, jeden z najciekawszych pod względem przyrodniczym regionów Europy Środkowej, został dość dobrze poznany pod wieloma względami, np. geologicznym, hydrologicznym, geobotanicznym, florystycznym. W dalszym ciągu jednak nie jest wystarczająco poznany pod względem mykologicznym, zwłaszcza w zakresie grzybów mikroskopijnych oraz organizmów grzybopodobnych. Trwające od kilku lat prace mające na celu podsumowanie dotychczasowego stanu zbadania tej grupy przyczyniły się do opublikowania kilku prac syntetyczno-analitycznych poświęconych kolejnym jednostkom taksonomicznym - rzędom, rodzajom czy gatunkom.

W obecnej pracy przygotowano wykaz organizmów grzybopodobnych należących do trzech rzędów w obrębie typu Oomycota - Albuginales, Peronosporales oraz Pythiales, podawanych dotychczas w granicach parków narodowych obu części Tatr - polskiej i słowackiej. Zamieszczono w nim gatunki znane przede wszystkim z literatury, uzupełniając część informacji o dane szczegółowe pochodzące z kolekcji zielnikowych.

Pierwsze dane o organizmach grzybopodobnych Tatr pojawiły się pod koniec XIX wieku w pracach Krupy $(1886,1888)$. Do chwili obecnej, a więc przez okres ponad 120 lat, publikacje dotyczące Oomycota były jednak nieliczne, a informacje na temat ich występowania bardzo ogólne. Na całym obszarze Tatr stwierdzono dotychczas zaledwie 32 gatunki na 57 gatunkach roślin, w tym dwa gatunki z rzędu Albuginales (rodzaje: Albugo i Pustula, na 9 gatunkach roślin), 29 gatunków z rzędu Peronosporales (rodzaje: Bremia, Hyaloperonospora, Peronospora oraz Plasmopara, na 49 gatunkach roślin), a także jeden gatunek z rzędu Pythiales (rodzaj: Myzocytium, na jednym gatunku glonu). Po polskiej stronie Tatr zebrano 29 gatunków, przy 
czym aż 26 w Tatrach Zachodnich. Po słowackiej stronie Tatr zanotowano zaledwie 10 gatunków, z czego najwięcej - 9 w Tatrach Wysokich (Vysoké Tatry). Wszystkie zebrano na 185 stanowiskach, przy czym 135 przypada na Tatry polskie (73\%), w tym aż 126 na polskie Tatry Zachodnie. Z kolei po stronie słowackiej Tatr najwięcej danych pochodzi z Tatr Wysokich (21 stanowisk).

Stan znajomości Oomycota w Tatrach jest więc bardzo słaby, a informacje o ich rozmieszczeniu rozproszone, wręcz przypadkowe. W przyszłości niezbędne są badania znacznie bardziej intensywne, przede wszystkim systematyczne, a obecny syntetyczny wykaz może być punktem wyjścia do ich rozpoczęcia. 